\title{
First Field Study of the Yellow-tailed Woolly Monkey
}

\author{
Mariella Leo Luna
}

After spending five months in Peru on the first field study of this rare monkey, which until 1974 was thought to be extinct (Oryx 13,1), the author believes that habitat destruction is the greatest threat to its survival, and that action to protect it now and provide refuges is urgent.

Believed to be extinct until it was rediscovered in 1974, the yellow-tailed woolly monkey Lagothrix flavicauda is one of the largest New World monkeys but the least known. It is found only in the humid and very humid forests over $1800 \mathrm{~m}$, in both branches of the East Andes chain, in the Peruvian state of Amazonas (between $5^{\circ} 30^{\prime}$ and $6^{\circ} 30^{\prime} \mathrm{S}, 77^{\circ} 20^{\prime}$ and $78^{\circ} 20^{\prime} \mathrm{W}$ ). It probably survives also in the Andes further north, in the same state near the Ecuadorian frontier, in the mountains between the Chiriaco and Nieva rivers (between $5^{\circ}$ and $5^{\circ} 30^{\prime} \mathrm{S}$ ), in the Campanquis chain in Loreto state, and in the northern chain in San Martín state.

\section{Habitat}

The monkey's habitat is one of steep gorges and ravines, with trees $20-40 \mathrm{~m}$ high, depending on the zone; the trunks are usually under $1 \mathrm{~m}$ diameter, except for some Cedrela sp. and Ficus spp. In the lower zones the understorey is dense with many Palmaceae species; on the most humid side of the mountain there are many vines and Bromeliaceae and Orchidaceae, and in the upper parts and on top 'suro' Chusquea sp. is a predominant. The variations result in several microclimates. The lowest temperature registered was $8^{\circ} \mathrm{C}$ (Santa Catalina and Yambrasbamba) and the highest $25^{\circ} \mathrm{C}$ (Yambrasbamba, Pucatambo, Shillac). Although the study was made in the so-called dry season (March-September) it drizzled almost every day, with changes in intensity and duration and occasional showers $(50 \mathrm{~mm}$ in 2 days in San Cristobal). Every morning the fog crept up the mountain, making the forest humid and cold.

\section{Social Behaviour}

The monkeys live in groups of four to ten adults. The proportion of males and females could not be determined, but the ratio of babies to juveniles/adults is small. One male appears to be 'chief' of the group. When an 'enemy' appears he tries to distract or frighten him (for example an observer), showing the genital zone, moving the hip, shaking or letting fall the tree branches. Sometimes he also urinates and defecates. Excited adults make a puppy-like noise - a very sharp bark that can be heard a great distance in the forest and can be confused with the sound made by Ateles sp. Reports from hunters that flavicauda occasionally mix with Ateles sp. were partly confirmed by direct observation: two adult flavicauda arrived at a tree where a group of Ateles sp. were settling down to sleep and showed signs of wanting to stay and sleep in the same tree. The main predator could be the puma $F$ elis concolor, but in some zones man must be considered the principal enemy. 


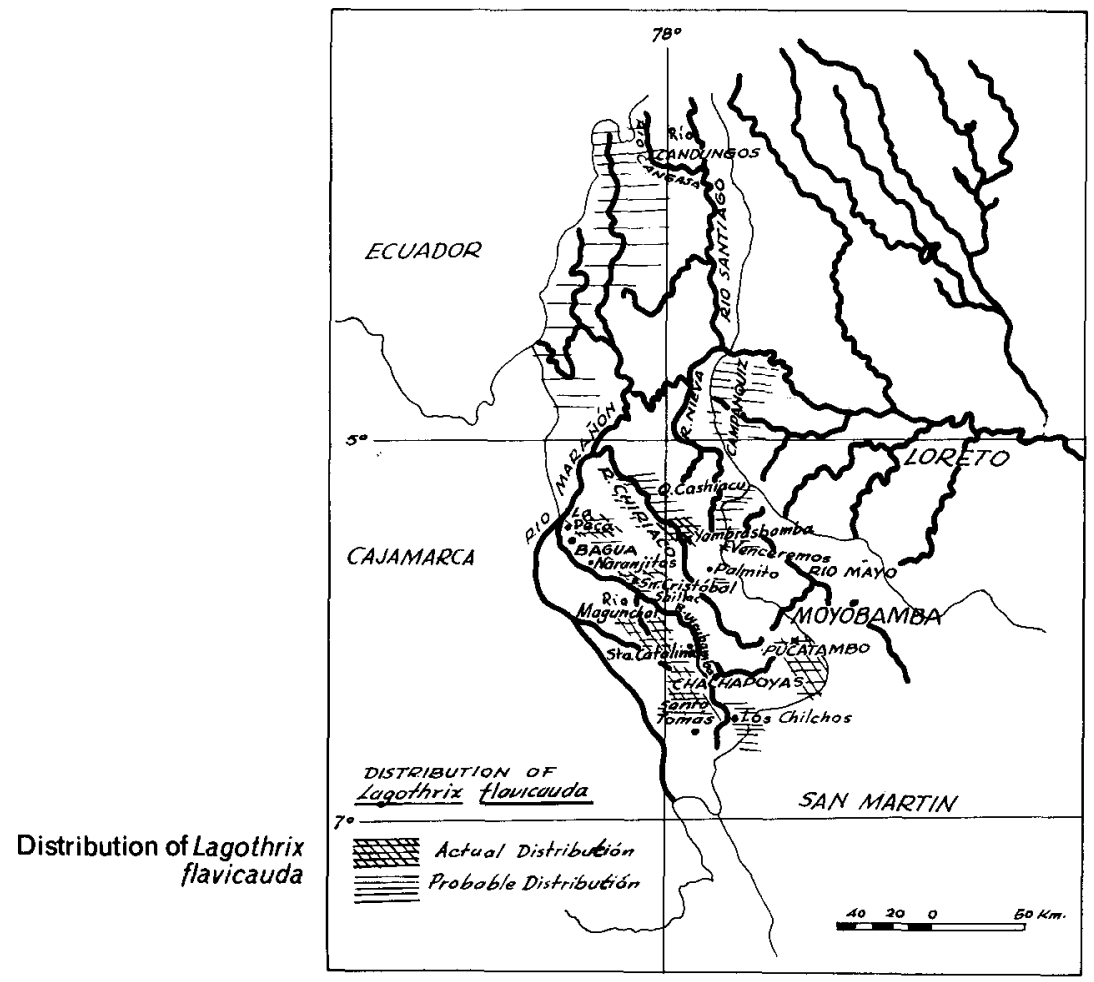

Diet

Diet is basically vegetable; a stomach analysis of an adult male killed by local hunters showed no insect or other animal residue. Fruit and flowers are the principle foods, and sometimes also succulent roots of epiphytes and petioles (Cecropia sp). Ficus spp. and Cecropia sp. are important foods, the first because it seems to fruit year round, and the second because it offers many kinds of food - inflorescences, fruits, big leaf-petioles, and terminal buds. (The author can supply a list of species known locally to be eaten by flavicauda.)

\section{Conservation Problems}

The monkey seems to have a low birth rate, with possibly only one birth per year per six adults (Table 2). This may be due to a high proportion of males, or to sexual maturity not being reached until after the age of four years, as in $L$. lagotricha, but it makes the species very vulnerable to even a little hunting pressure. Habitat destruction, however, is the worst danger. In all the localities visited in this study, the woods are being cut down, especially on-the less steep slopes where humidity is high, which are the best places for Ficus spp. and Cedrela. The cutting is still only on a small scale, but is bound to increase.

\section{Areas for Reserves}

L. flavicauda is the only one of the 20 primate species in Peru that is not protected in a reserved area, which condemns it to extinction in the next 50 years, A reserved area in the state of Amazonas (or between this state and San Martin) would protect not only L. flavicauda but also the spectacled bear Tremarctos ornatus, the cock of the rock Rupicola peruviana, and the marvellous spatuletail Loddigesia mirabilis. ${ }^{5}$ Of the eight localities visited in this study, 
Table 1

Distribution in Amazonas, San Martin and Loreto

\begin{tabular}{|c|c|c|c|c|}
\hline Locality & Source & $\begin{array}{l}\text { Altitude } \\
\text { in meters }\end{array}$ & Life Zone & Local Name \\
\hline $\begin{array}{l}\text { Upper part of } \\
\text { Cangas river }\end{array}$ & $\begin{array}{c}\mathbf{R} \\
(1959)\end{array}$ & - & - & - \\
\hline $\begin{array}{l}\text { Campanquís } \\
\text { mountains }\end{array}$ & $\begin{array}{c}\mathbf{R} \\
(1959)\end{array}$ & - & $\begin{array}{l}\text { bp-PT and } \\
\text { bp-MBT }\end{array}$ & chú (?) \\
\hline $\begin{array}{l}\text { Cashiaco } \\
\text { river }\end{array}$ & $\mathbf{R}$ & & $\begin{array}{l}\text { bp-MBT } \\
\text { bp-PT }\end{array}$ & chú (?) \\
\hline El Arenal & $\begin{array}{l}\mathrm{O} \\
\mathrm{S}\end{array}$ & $\begin{array}{l}1800 \text { to } \\
2200\end{array}$ & $\begin{array}{l}\text { bh-PT and } \\
\text { bh-MBT }\end{array}$ & choba \\
\hline San Cristobal & O & - & bh-PT & pacorrunto \\
\hline Naranjitos & $\mathbf{R}$ & - & bh-PT & - \\
\hline Shillac & $\mathrm{O}$ & $\begin{array}{l}1800 \text { to } \\
2300\end{array}$ & $\begin{array}{r}\text { bh-PT and } \\
\text { bh-MBT }\end{array}$ & tupa \\
\hline Yambrasbamba & $\mathbf{P}$ & $\begin{array}{l}1900 \text { to } \\
2100\end{array}$ & bh-PT & pacorrunto \\
\hline Palmito Mountain & $\mathbf{R}$ & - & - & - \\
\hline Santa Catalina & $\mathrm{O}$ & $\begin{array}{l}2380 \text { to } \\
2500\end{array}$ & $\begin{array}{l}\text { bmh-MBT and } \\
\text { bmh-MT }\end{array}$ & pacorrunto \\
\hline Magunchal river & $\mathbf{R}$ & - & - & - \\
\hline Lonya Chico & $\underset{(1956)}{\stackrel{R}{19}}$ & - & bh-MBT & - \\
\hline Santo Tomás & $\begin{array}{c}\mathbf{R} \\
(1956)\end{array}$ & - & bh-MBT & - \\
\hline $\begin{array}{l}\text { Los Chilcho } \\
\text { valley }\end{array}$ & $\mathbf{R}$ & - & $\begin{array}{c}\text { bmh-MBT and } \\
\text { bp-MT }\end{array}$ & $\begin{array}{c}\text { mono barroso } \\
\text { (?) }\end{array}$ \\
\hline Yascayacu river & $\underset{(1963)}{\mathbf{R}}$ & & & \\
\hline Venceremos & $\mathbf{R}$ & & & \\
\hline Pucatambo & $\underset{\mathrm{V}}{\mathrm{R}}$ & $\begin{array}{l}1600 \text { to } \\
2100\end{array}$ & bmh-PT & quillirunto \\
\hline
\end{tabular}

$\mathrm{R}$ : referred by local hunters (year that they were in the zone); $\mathrm{O}$ : visual observation; S: skins; $\mathrm{V}$ : voice observation; B: references; bh-PT: tropical pre-montane humid forest; bh-MBT: tropical low montane humid forest; bmh-PT: tropical pre-montane very humid forest; bmh-MBT: tropical low montane very humid forest; bp-PT: tropical pre-montane rainy forest; bp-MBT: tropical low montane rainy forest; (according to ONERN ${ }^{8}$ )

Table 2 Group Composition

\begin{tabular}{lcccc}
\hline \multicolumn{1}{c}{ Locality } & Adults & Males/ Females & Babies & Juveniles \\
\hline Shillac 1 & 8 & - & - & - \\
Shillac $2^{\dagger}$ & 4 & - & 1 & 1 \\
Shillac $3^{\dagger}$ & 4 & 1. & 1 & 1 \\
San Cristobal 1 & 2 & - & - & - \\
Shillac 4 & $4^{*}$ & $1 /$ & 1 & - \\
Shillac 5 & 9 & $2 / 2^{*}$ & 2 & 1 \\
Shillac 6 & 7 & $1^{*}$ & - & 1 \\
El Arenal & 10 & $3 / 2$ & - & - \\
El Arenal & 6 & $2 /$ & - & 2 \\
El Arenal & $5^{*}$ & 3 & - & - \\
Santa Catalina & 6 & $2 / 3$ & - & 2 \\
Santa Catalina 2 & 7 & & & \\
\hline
\end{tabular}

†It seems to be the same group

*Probably a larger number 
only three satisified the basic requirements for a reserved area: the Chiriaco's river forest, between Yambrasbamba and the north forest where the monkey is believed to occur; the Pucatambo forests and the mountains of Rodriguez de Mendoza, between the states of Amazonas and San Martin; and the Los Chilchos Valley. The zone between the headwaters of the Nieva and Chiriaco rivers (which could not be visited) seems to have better possibilities. Another study is needed to determine the best locality and find out the density and population status. Meanwhile, the Government, through the Ministry of Agriculture and with the help of the Forest Police, should take measures to control illegal hunting.

In five months spent on this study, six groups of flavicauda were observed for periods not longer than one and a half hours. From the observations in the field coupled with information from local hunters it was possible to get some idea of the species' biology and ecology, and to realise the dangers which threaten yellow-tailed woolly monkeys.

\section{Acknowledgments}

I would like to thank Dr Antonio Brack-Egg of the Ministerio de Agriculture, who administers the project. Special thanks also go to Bernard Peyton III, of the New York Zoological Society, who contributed with his experience of field work; to José María Guallart SJ, linguist and naturalist, who has worked for over twenty years in the upper part of the Maranón river; to undergraduate Roberto Rodríguez, who was in charge of a study on Amazonas mammals; Daniel La Torre, good guide and best friend, without whose help this study would have been more difficult; and to Gary Graham, Tom Schulemberg, Philips Barbour and Lynn Berkley (graduates of Louisiana University), who lodged us in their camp in El Arenal Mountains, and to Marisa Chavez Taffur who corrected this manuscript. The study was partly supported by a New York Zoological Society grant and by Bernard Peyton III.

\section{References}

1. CABRERA, A. 1958. Catálogo de los Mamíferos de América del Sur. I. Cienc. Zool. 4,1. Museo Arq. y Cienc. Nat. B. Rivadivia, Buenos Aires, Argentina.

2. FOODEN, J. 1963. A Revision of the Woolly Monkeys (genus Lagothrix). F. Mammal 44,2: 213-47.

3. IZAWA, K. 1975. Foods and Feeding Behaviour of the Monkeys in the Upper Amazon Basin. Primates 16: 295-316.

4. GRIMWOOD, I. Notes on the Distribution of Peruvian Mammals. Special publication, New York Zoological Society.

5. MITTERMEIER, R.A., D. de MACEDO-RUIZ and A. LUSCOMBE 1975. A Woolly Monkey Rediscovered in Peru. Oryx 13: 41-6.

6. MITTERMEIER, R.A., H. de MACEDO-RUIZ and A. LUSCOMBE 1977. Rediscovery and Conservation of the Peruvian Yellow Tailed Woolly Monkey (Lagothrix flavicauda). Primate Conservation.

7. NAPIER, J.R., and P.H. NAPIER 1967. A handbook of Living Primates. Academic Press, London/New York.

8. O.N.E.R.N. 1976. Mapa Ecológico del Perú. Lima.

9. PEYTON, B. 1978. Pers. comm.

10. THOMAS, O. 1927a. A Remarkable New Monkey from Peru. Ann. Mag. Nat. Hist. 9,19: 156-7.

11. THOMAS, O. 1927b. The Godman-Thomas Expedition to Peru VI. Ann. Mag. Nat. Hist. 9,20: 594-608. 